\title{
Inventarytation of medicinal plants as a self-medication by the Tolaki, Puundoho village, North Kolaka regency, Southeast Sulawesi
}

\section{Inventarisasi tumbuhan obat sebagai upaya swamedikasi oleh masyarakat Suku Tolaki Desa Puundoho, Kabupaten Kolaka Utara, Sulawesi Tenggara}

\author{
Hasria Alang*, Hastuti, Muhammad Sri Yusal
}

Jurusan Biologi, STKIP-Pembangunan Indonesia, Makassar

*Corresponding author: hasriaalangbio@gmail.com

\begin{abstract}
Background: Traditional medicine knowledge is one of the local wisdoms and is passed down from generation to generation. Traditional medicine needs to be preserved in order to maintain the continuity of this knowledge; besides that, it requires a balance between modern medicine and herbal medicine. Herbal medicine is easy to obtain in the surrounding environment, at affordable prices and guarantees the safety of medicinal chemicals that are harmful to the body. The use of drugs for a long period of time is a habit that is harmful to the body organs because they contain certain chemical compounds that are not safe for human vital organs, so it is necessary to make an inventory effort by digging up information from traditional healers. This research is expected to make a significant contribution so that the role of herbal plants can be maintained and developed in the future.

Objective: to inventory the plant species which useful as traditional medicines used by traditional healers of the Tolaki tribe in Puundoho village.

Method: The method used in this research is a qualitative exploration, through an emic approach or a community and ethical perspective supported by scientific literature. The use of qualitative methods in this study is intended to describe people's knowledge

Results: The interview results with three traditional healers (mbu'wai) in Puundoho village about plants that can be used as traditional medicines. It can be found on the side of the road, garden and yard. The part of the plant used is the whole plant or part of the plant such as roots, stems, or leaves. The method to blend it is boiled or mashed. The use of traditional medicines is applied orally or topically.

Conclusion: The types of traditional medicinal plants used by the Tolaki tribe in Puundoho village can be obtained from yards, gardens, and roadsides including sidaguri, ciplukan, jeringan, bangle, purslane, bandotan, boborongan, turi, meniran, banjar berrywit, mesoyi, ketepeng, guava, ginger, kencur, blechnum nails and ketepeng
\end{abstract}

Keywords: Herbal medicine, inventarytation, medicinal plants, traditional medicine

\section{Intisari}

Latar belakang: Pengetahuan pengobatan tradisional merupakan salah satu kearifan lokal dan diperoleh secara turun-temurun dari generasi kegenerasi selanjutnya. Pengobatan tradisional perlu dilestarikan untuk menjaga keberlangsungan pengetahuan tersebut, selain itu diperlukan suatu keseimbangan antara pengobatan modern dengan pengobatan herbal. Pengobatan herbal mudah diperoleh di lingkungan sekitarnya, harga terjangkau, dan jaminan keamanan dari bahan kimia obat yang berbahaya bagi tubuh. Penggunaan obat dalam jangka waktu yang lama adalah kebiasaan yang berbahaya bagi organ tubuh karena mengandung senyawa kimia tertentu yang tidak aman bagi organ vital manusia sehingga perlu dilakukan upaya inventarisasi dengan cara menggali informasi dari para penyehat tradisional. Penelitian ini diharapkan akan memberikan kontribusi yang signifikan, sehingga peran tanaman herbal dapat terus terjaga dan dikembangkan di waktu mendatang.

Tujuan: Menginventarisasi jenis-jenis tumbuhan yang bermanfaat sebagai obat tradisional yang digunakan oleh penyehat tradisional suku Tolaki di Desa Puundoho.

Metode: Metode yang digunakan dalam penelitian ini adalah eksplorasi yang bersifat kualitatif, melalui pendekatan emik atau perspektif masyarakat dan etik yang didukung literatur ilmiah. Penggunaan metode kualitatif dalam penelitian ini dimaksudkan untuk mendeskripsikan pengetahuan masyarakat

Hasil: Hasil wawancara dengan tiga penyehat tradisional (mbu'wai) yang ada di Desa Puundoho tentang tumbuhan yang dapat digunakan sebagai obat tradisional dapat ditemukan di tepi jalan, kebun dan 
pekarangan. Bagian tanaman yang digunakan adalah keseluruhan bagian tanaman atau sebagian tanaman seperti akar, batang atau daun. Cara meramunya yaitu direbus atau dihaluskan. Penggunaan obat tradisional tersebut dilakukan secara cara oral atau topikal.

Kesimpulan: Jenis tanaman obat tradisional yang digunakan oleh suku Tolaki di desa Puundoho dapat diperoleh dari pekarangan, kebun, dan pinggir jalan diantaranya sidaguri, ciplukan, jeringan, bangle, krokot, bandotan, boborongan, turi, meniran, rumput beriwit banjar, mesoyi, ketepeng, jambu air, jahe, kencur, paku blechnum dan ketepeng.

Kata kunci: Inventarisasi, obat herbal, pengobatan tradisional, tanaman obat

\section{Pendahuluan}

Sejak zaman prasejarah, manusia telah menggunakan produk herbal yang berasal dari tanaman untuk pengobatan penyakit dan berbagai keperluan lain yang berhubungan dengan kesehatan manusia (Yuan et al., 2016). Informasi tentang tanaman obat sejak dahulu kala diturunkan dari generasi ke generasi (Jamshidi-Kia et al., 2018). Pengetahuan pemanfaatan tumbuhan dalam pengobatan tradisonal oleh masyarakat Indonesia diwariskan dari nenek moyangnya pada sebuah keluarga sehingga menjadi kebiasaan yang tetap bertahan (Rahim, 2013). Tumbuhan sebagai tanaman obat tradisional termasuk rempah, buah, sayur dan juga tumbuhan liar. Tingginya kekayaan alam Indonesia serta komunitas atau etnis suku yang beragam, memunculkan berbagai pengetahuan tentang lingkungan alam. Beberapa manfaat tanaman tersebut telah didapatkan melalui berdasar pengetahuan tentang lingkungan alam, termasuk pemanfaatan bahan alam untuk meningkatkan derajat kesehatan. Tiap suku atau etnis di Indonesia memiliki pengetahuan yang berbeda dalam pemanfaatan bahan alam sebagai sumber obat-obatan. Hal ini dipengaruhi oleh perbedaan tempat tinggal, adat ataupun tata-cara dan perilaku. Menggali pengetahuan masyarakat tradisional (indigenous knowledge) adalah salah satu langkah awal untuk mengetahui tumbuhan yang berkhasiat sebagai obat. Windadri et al. (2006) menyatakan bahwa tradisi pemanfaatan tumbuhan sebagai obat tradisional telah dibuktikan secara ilmiah, namun masih banyak yang belum disebarluaskan melalui publikasi.

Suku Tolaki merupakan salah satu komunitas di Propinsi Sulawesi Tenggara yang mendiami beberapa daerah pedesaan, termasuk Desa Puundoho. Nilai kearifan lokal yang berasal dari alam dan lingkungan sekitar menjadi ciri khas komunitas suku tersebut. Salah satu bentuk dan kearifan lokal komunitas tersebut adalah penggunaan obat-obatan tradisional berbahan alam atau tumbuhan sekitar. Namun, pengetahuan tentang pemanfaatan tumbuhan sebagai obat ini cenderung hanya diketahui oleh kelompok tertentu seperti penyehat tradisional, sehingga tidak semua anggota masyarakat atau anggota suku mengetahuinya. Seiring dengan perkembangan zaman dan modernisasi, berubahnya ekosistem tempat mereka hidup, perubahan lingkungan dan arus lalu lintas, komunikasi dan informasi dari luar, serta pola hidup yang serba instan menyebabkan nilai-nilai budaya yang selama ini tumbuh dan berkembang di masyarakat ikut berkembang, namun di sisi lain pengetahuan pemanfaatan dan cara meramu tumbuhan obat mulai mengalami pergeseran minat dari kalangan generasi muda akibat adanya penggunaan obat 
secara modern dan bersifat instant (Wijayakusuma, 2000), sehingga kearifan lokal terkait pemanfaatan bahan alam dalam pengobatan penyakit terancam akan hilang. Pengobatan penyakit yang berbahan alam perlu dilakukan guna meningkatkan derajat kesehatan untuk mendukung animo masyarakat "back to nature" yang kini juga digemari bahkan oleh bangsa barat (Setyowati \& Wardah, 2007). Kuntorini (2005) menyatakan bahwa penelitian mengenai inventarisasi tanaman sebagai obat tradisional telah banyak dilakukan oleh peneliti-peneliti terdahulu. Rahayu \& Rugayah (2007) melakukan inventarisasi pada masyarakat lokal pulau Wawonii Sulawesi Tenggara, Indrawati et al. (2015) pada masyarakat di Kelurahan Lipu Kecamatan Betoambari Kota Baubau Provinsi Sulawesi Tenggara, Hasanah et al. (2016) di Desa Lapandewa Kaindea kecamatan Lapandewa Kabupaten Buton Selatan, dan Slamet \& Andarias (2018) pada Sub Etnis Wolio Kota Baubau Sulawesi Tenggara.

Survei etnobotani tentang tumbuhan yang berperan sebagai obat tradisional pada masyarakat suku Tolaki Kolaka Utara belum pernah dilaporkan. Tujuan kegiatan ini adalah untuk menginventarisasi jenis-jenis tumbuhan yang bermanfaat sebagai obat tradisional yang digunakan oleh penyehat tradisional suku Tolaki di Desa Puundoho. Inventarisasi ini diharapkan dapat menambah khazanah pengetahuan bagi para peneliti yang ingin mengembangkan riset tentang peran tanaman herbal sehingga obat tradisional dapat dikembangkan bagi kesehatan masyarakat di waktu mendatang. Selain itu dengan adanya inventarisasi ini diharapkan agar pengetahuan pengobatan tradisional dapat terus disebarluaskan dan diketahui oleh generasigenerasi berikutnya.

\section{Metode}

\subsection{Waktu dan tempat}

Penelitian ini dilaksanakan pada bulan September 2020 di Desa Puundoho, Kecamatan pakue Utara, Kabupaten Kolaka Utara, Propinsi Sulawesi Tenggara.

\subsection{Teknik pengumpulan data}

Metode yang digunakan dalam penelitian ini adalah eksplorasi yang bersifat kualitatif, melalui pendekatan emik atau perspektif masyarakat dan etik yang didukung literatur ilmiah. Penggunaan metode kualitatif dalam penelitian ini dimaksudkan untuk mendeskripsikan pengetahuan masyarakat. Pengumpulan data dilakukan melalui observasi, wawancara dan identifikasi. Observasi dilakukan dengan mengamati jenis tumbuhan yang ada dilapangan kemudian mendokumentasikan jenis tumbuhan yang ditemukan berdasarkan rekomendasi dari responden yang membantu menunjukkan tumbuhan yang dicari secara langsung. Wawancara dilakukan kepada penyehat tradisional (mbu'uwai) suku Tolaki di Desa Puundoho. Identifikasi nama ilmiah jenis tumbuhan yang digunakan sebagai obat tradisional yang mengacu pada buku 
Taksonomi Tumbuhan Obat-obatan dan buku Flora (Tjitrosoepomo, 2005). Analisis data dilakukan secara deskriptif.

\section{Hasil dan pembahasan}

Tumbuhan obat adalah tumbuhan yang mengandung bahan untuk pengobatan. Pemanfaatan tumbuhan sebagai obat-obatan oleh suatu adat suku bangsa disebut etnomedis yang meliputi keseluruhan bagian tumbuhan, atau sebagian tubuh tumbuhan seperti daun, bunga, buah, biji, batang, kulit, akar atau rimpang. Hal ini dikarenakan adanya bahan aktif (fitokimia) yang terkandung dalam suatu tanaman yang memiliki aktivitas farmakologi (aktivitas sebagai obat), diantaranya antioksidan, analgesik (penghilang rasa nyeri), antipiretik (menurunkan suhu tubuh), antinflamasi (anti-radang), antitusif (anti-batuk). Selanjutnya hasil wawancara dengan tiga penyehat tradisional (mbu'wai) yang ada di Desa Puundoho tentang tumbuhan yang dapat digunakan sebagai obat tradisional selengkapnya dapat dilihat pada Tabel 1.

Tabel 1. Tumbuhan berkhasiat obat yang dimanfaatkan masyarakat suku Tolaki

\begin{tabular}{cccc}
\hline No & Nama Lokal & Nama Umum & Nama Ilmiah \\
\hline 1 & Tamiau & Ciplukan & Physalis angulata \\
2 & Solumba & Sidaguri & Sida rhombifolia \\
3 & Daria & Jeringau & Acorus calamus \\
4 & Panini & Bangle & Zingiber cassumunar \\
5 & Tagurisa & Krokot & Portulaca oleracea \\
6 & Tawa Bembe & Bandotan & Ageratum conyzoides \\
7 & Tahusosangia & Boborongan & Hyptis brevis \\
8 & Taluma & Turi & Sesbania grandiflora \\
9 & Ocempa & Meniran & Phyllanthus urinaria \\
10 & Bulandia & Rumput beriwit & Paspalum conjugatum \\
11 & Adinge & Massoyi & Cryptocarya massoia \\
12 & Tawa sabandara & Ketepeng & Senna alata \\
13 & Tawa dambu & Jambu air & Psidium guajava \\
14 & Lo'io & Jahe & Zingiber officinale \\
15 & O'kudu & Kencur & Kaempferia galanga \\
16 & O'bite & Daun sirih & Piper betle \\
17 & Taluede & Paku Blechnum & Blechnum sp \\
\hline
\end{tabular}

Jenis tumbuhan yang digunakan sebagai bahan obat tradisional oleh suku Tolaki merupakan tumbuhan budidaya dan non budidaya. Tumbuhan ini mudah ditemukan dipekarangan, pinggir jalan dan kebun (Tabel 2). Hasil penelitian Hasanah et al. (2016) terlihat bahwa masyarakat di Lapandewa Kaindea Buton Selatan juga memperoleh tumbuhan dari pekarangan atau kebun bahkan hutan yang digunakan sebagai tumbuhan obat. Hal ini sesuai dengan Sofian et al. (2013) yang menyatakan bahwa pekarangan merupakan awal pemanfaatan sumberdaya alam yang berpotensi terutama sebagai obat, dan sebagai pencegahan dan pengobatan pertama bagi keluarga. 
Tabel 2. Jenis tumbuhan berkhasiat obat tradisional yang ditemukan di Desa Puundoho beserta tempat tumbuhnya

\begin{tabular}{ccccc}
\hline No & Family & Nama Umum & Tempat tumbuh & Keterangan \\
\hline 1 & Solanaceae & Ciplukan & Kebun dan pinggir jalan & Non budidaya \\
2 & Malvaceae & Sidaguri & Kebun dan pinggir jalan & Non budidaya \\
3 & Acoraceae & Jeringau & Kebun dan pekarangan & Budidaya \\
4 & Zingiberaceae & Bangle & Kebun dan pekarangan & Budidaya \\
5 & Portulacaceae & Krokot & Pekarangan, pinggir jalan dan kebun & Non budidaya \\
6 & Asteraceae & Bandotan & Pekarangan, pinggir jalan dan kebun & Non budidaya \\
7 & Lamiaceae & Boborongan & Pekarangan, pinggir jalan dan kebun & Non budidaya \\
8 & Fabaceae & Turi & Kebun, pekarangan & Budidaya \\
9 & Euphorbiaceae & Meniran & Pekarangan, pinggir jalan dan kebun & Non budidaya \\
10 & Anthocerotaceae & Rumput beriwit & Pekarangan, pinggir jalan dan kebun & Non budidaya \\
& & & & Kudidaya \\
11 & Lauraceae & Massoyi & Kebun dan hutan & Non budidaya \\
12 & Fabaceae & Ketepeng & Pinggir jalan dan kebun & Budidaya \\
13 & Myrtaceae & Jambu air & Pekarangan dan kebun & Budidaya \\
14 & Zingiberaceae & Jahe & Pekarangan dan kebun & Budidaya \\
15 & Zingiberaceae & Kencur & Pekarangan dan kebun & Budidaya \\
16 & Piperaceae & Daun sirih & Pekarangan dan kebun & Non budidaya \\
17 & Blechnaceae & Paku Blechnum & Kebun dan hutan & \\
\hline
\end{tabular}

Organ atau bagian tanaman yang digunakan untuk pengobatan adalah keseluruhan tanaman, atau sebagian misalnya daun, batang dan rimpang. Hal ini sesuai dengan penelitian Indrawati et al. (2015), Qamariah et al. (2018) dan Yowa et al. (2019) yang menyatakan bahwa bagian tanaman yang digunakan sebagai obat yaitu daun, batang, kulit batang, bunga, buah, biji, umbi, getah, rimpang dan akar yang pengolahannya dilakukan dengan cara ditumbuk, direbus, diremas, dilayukan, dipanggang, diseduh, diparut dan ditempel atau dibalur. Hal ini dikarenakan tiap organ yang dimiliki oleh suatu tumbuhan memiliki kandungan senyawa kimia yang berbeda sehingga khasiatnya pun berbeda-beda (Pei et al., 2009). Dosis penggunaan obat radisional oleh suku Tolaki juga memakai ukuran sederhana seperti segenggam, helai, dan ukuran ruas jari seperti terlihat pada Tabel 3.

Tabel 3. Organ tumbuhan, cara meramu dan khasiat obat tradisional oleh masyarakat Desa Puundoho

\begin{tabular}{|c|c|c|c|c|c|}
\hline No & Bahasa lokal & $\begin{array}{c}\text { Organ } \\
\text { tanaman } \\
\text { yang } \\
\text { digunakan }\end{array}$ & Khasiat & Cara meramu & Cara penggunaan \\
\hline \multirow[t]{2}{*}{1} & Tamiau & $\begin{array}{l}\text { Seluruh } \\
\text { organ } \\
\text { Tanaman }\end{array}$ & $\begin{array}{l}\text { Mengobati } \\
\text { kolesterol, } \\
\text { sakit perut, } \\
\text { gondok } \\
\text { beracun }\end{array}$ & $\begin{array}{l}\text { Untuk mengobati } \\
\text { kolesterol dan gondok } \\
\text { beracun dengan cara } \\
\text { keseluruhan tanaman } \\
\text { di rebus dengan tiga } \\
\text { gelas air, hingga tersisa } \\
\text { satu gelas }\end{array}$ & $\begin{array}{l}\text { Air rebusan } \\
\text { tersebut diminum }\end{array}$ \\
\hline & & & & $\begin{array}{l}\text { Untuk mengobatai } \\
\text { sakit perut dengan cara } \\
\text { merebus segenggam } \\
\text { daun tanaman tersebut } \\
\text { dengan tiga gelas air }\end{array}$ & \\
\hline
\end{tabular}




\begin{tabular}{|c|c|c|c|c|c|}
\hline No & Bahasa lokal & $\begin{array}{c}\text { Organ } \\
\text { tanaman } \\
\text { yang } \\
\text { digunakan } \\
\end{array}$ & Khasiat & Cara meramu & Cara penggunaan \\
\hline & & & & $\begin{array}{l}\text { hingga tersisa satu } \\
\text { gelas }\end{array}$ & \\
\hline \multirow[t]{2}{*}{2} & Solumba & Bunga & $\begin{array}{l}\text { Mengobati } \\
\text { bisul (yang } \\
\text { tidak meletus) } \\
\text { dan buang air } \\
\text { besar darah }\end{array}$ & $\begin{array}{l}\text { Untuk mengobati bisul } \\
\text { dilakukan dengan cara } \\
\text { mengambil bagian } \\
\text { bunga tanaman } \\
\text { tersebut, selanjutnya } \\
\text { bunga tersebut } \\
\text { diremas dan }\end{array}$ & $\begin{array}{l}\text { Ditempelkan pada } \\
\text { permukaan bisul }\end{array}$ \\
\hline & & & & $\begin{array}{l}\text { Untuk mengobati BAB } \\
\text { berdarah dilaukan } \\
\text { dengan cara } \\
\text { mengambil segenggam } \\
\text { daun tanaman tersebut } \\
\text { dan diremas dengan } \\
\text { satu suing bawang } \\
\text { merah hingga lunak } \\
\text { dan berair }\end{array}$ & $\begin{array}{l}\text { Air remasan } \\
\text { diminum }\end{array}$ \\
\hline 3 & Daria & Rimpang & $\begin{array}{l}\text { Mengobati } \\
\text { sakit perut }\end{array}$ & $\begin{array}{l}\text { Caranya dengan } \\
\text { mengambil satu ruas } \\
\text { rimpang tanaman } \\
\text { tersebut, selanjutnya } \\
\text { dihaluskan }\end{array}$ & $\begin{array}{l}\text { Ditempelkan pada } \\
\text { perut yang sakit }\end{array}$ \\
\hline 4 & Panini & Rimpang & $\begin{array}{l}\text { Mengobati } \\
\text { sakit perut, bab } \\
\text { berdarah dan } \\
\text { demam }\end{array}$ & $\begin{array}{l}\text { Untuk mengobati sakit } \\
\text { perut, bab berdarah } \\
\text { dan demam dilakukan } \\
\text { dengan cara } \\
\text { mengambil satu ruas } \\
\text { rimpang tanaman } \\
\text { tersebut, selanjutnya } \\
\text { dihaluskan }\end{array}$ & $\begin{array}{l}\text { Ditempelkan pada } \\
\text { perut yang sakit, } \\
\text { dan untuk demam } \\
\text { dilakukan dengan } \\
\text { cara menempelkan } \\
\text { pada jidat } \\
\text { Untuk mengobati } \\
\text { bab berdarah } \\
\text { dengan cara } \\
\text { setelah tanaman } \\
\text { tersebut halus, } \\
\text { selanjutnya } \\
\text { diperas dan air } \\
\text { perasan tersebut } \\
\text { selanjunya } \\
\text { diminum }\end{array}$ \\
\hline 5 & Tagurisa & $\begin{array}{l}\text { Seluruh } \\
\text { bagian } \\
\text { tanaman }\end{array}$ & $\begin{array}{l}\text { Memudahkan } \\
\text { persalinan dan } \\
\text { mengobati } \\
\text { penyakit } \\
\text { jantung }\end{array}$ & $\begin{array}{l}\text { Seganggam tanaman } \\
\text { tersebut diremas } \\
\text { Merebus keseluruhan } \\
\text { akar, batang dan daun } \\
\text { tanaman dengan tiga } \\
\text { gelas air hingga tersisa } \\
\text { satu gelas }\end{array}$ & $\begin{array}{l}\text { Dioleskan pada } \\
\text { perut ibu yang } \\
\text { menjelang } \\
\text { melahirkan } \\
\text { Meminum air } \\
\text { rebusan tanaman } \\
\text { krokot tersebut }\end{array}$ \\
\hline
\end{tabular}




\begin{tabular}{|c|c|c|c|c|c|}
\hline No & Bahasa lokal & $\begin{array}{c}\text { Organ } \\
\text { tanaman } \\
\text { yang } \\
\text { digunakan }\end{array}$ & Khasiat & Cara meramu & Cara penggunaan \\
\hline 6 & Tawa Bembe & Daun & $\begin{array}{l}\text { Untuk } \\
\text { mencegah } \\
\text { pendarahan } \\
\text { pada luka }\end{array}$ & $\begin{array}{l}\text { Meremas segenggam } \\
\text { daun tersebut hingga } \\
\text { lunak dan berair }\end{array}$ & $\begin{array}{l}\text { Ditempelkan/dibal } \\
\text { ur pada luka }\end{array}$ \\
\hline 7 & Tahusosangia & Daun & $\begin{array}{l}\text { Untuk } \\
\text { menghilangkan } \\
\text { bau amis pada } \\
\text { darah haid }\end{array}$ & $\begin{array}{l}\text { Mengambil segenggam } \\
\text { daun tanaman } \\
\text { tersebut, kemudian } \\
\text { direbus dengan tiga } \\
\text { gelas air hingga tersisa } \\
\text { satu gelas }\end{array}$ & $\begin{array}{l}\text { Meminum air } \\
\text { rebusan tanaman } \\
\text { tersebut }\end{array}$ \\
\hline \multirow[t]{2}{*}{8} & \multirow[t]{2}{*}{ Taluma } & \multirow[t]{2}{*}{ Daun } & \multirow[t]{2}{*}{$\begin{array}{l}\text { Untuk luka } \\
\text { dalam dan } \\
\text { panas dalam } \\
\text { pada } \\
\text { anak/balita }\end{array}$} & $\begin{array}{l}\text { Untuk luka dalam } \\
\text { dengan cara } \\
\text { mengambil segenggam } \\
\text { daun tanaman } \\
\text { tersebut, kemudian } \\
\text { direbus dengan tiga } \\
\text { gelas air hingga tersisa } \\
\text { satu gelas }\end{array}$ & $\begin{array}{l}\text { Meminum air } \\
\text { rebusan tanaman } \\
\text { tersebut }\end{array}$ \\
\hline & & & & $\begin{array}{l}\text { Mengambil segenggam } \\
\text { daun tanaman } \\
\text { tersebut, kemudian } \\
\text { dihaluskan dengan } \\
\text { segenggam beras. } \\
\text { Ditumbuk hingga halus }\end{array}$ & $\begin{array}{l}\text { sedikit air hingga } \\
\text { membentuk krim, } \\
\text { kemudian } \\
\text { dibalurkan pada } \\
\text { seluruh tubuh } \\
\text { anak/balita }\end{array}$ \\
\hline 9 & Ocempa' & $\begin{array}{l}\text { Seluruh } \\
\text { bagian } \\
\text { tanaman }\end{array}$ & $\begin{array}{l}\text { Mengobati } \\
\text { infeksi saluran } \\
\text { kemih }\end{array}$ & $\begin{array}{l}\text { Mengambil } \\
\text { keseluruhan bagian } \\
\text { tanaman, Direbus } \\
\text { dengan tiga gelas air } \\
\text { hingga tersisa satu } \\
\text { gelas }\end{array}$ & $\begin{array}{l}\text { Air rebusan } \\
\text { tersebut diminum }\end{array}$ \\
\hline 10 & Bulandia & $\begin{array}{l}\text { Rumput } \\
\text { dawit } \\
\text { banjar }\end{array}$ & $\begin{array}{l}\text { Untuk } \\
\text { mencegah } \\
\text { pendarahan } \\
\text { pada luka }\end{array}$ & $\begin{array}{l}\text { Meremas segenggam } \\
\text { daun tersebut hingga } \\
\text { lunak dan berair }\end{array}$ & $\begin{array}{l}\text { Ditempelkan/ } \\
\text { dibalur pada luka }\end{array}$ \\
\hline 11 & Adinge & Kulit batang & $\begin{array}{l}\text { Untuk luka } \\
\text { (borok) }\end{array}$ & $\begin{array}{l}\text { Mengambil kulit batang } \\
\text { tanaman tersebut } \\
\text { sebanyak dua ruas jari, } \\
\text { kemudian dihaluskan } \\
\text { dengan segenggam } \\
\text { beras. Campur sedikit } \\
\text { air hingga membentuk } \\
\text { krim }\end{array}$ & $\begin{array}{l}\text { Ditempelkan/ } \\
\text { dibalur pada luka } \\
\text { borok }\end{array}$ \\
\hline 12 & $\begin{array}{c}\text { Tawa } \\
\text { sabandara }\end{array}$ & Daun & $\begin{array}{l}\text { Mengobati } \\
\text { panu dan } \\
\text { kurap }\end{array}$ & $\begin{array}{l}\text { Mengambil segenggam } \\
\text { daun tanaman } \\
\text { tersebut, kemudian } \\
\text { diremas }\end{array}$ & $\begin{array}{l}\text { Digosokkan pada } \\
\text { kulit yang } \\
\text { terinfeksi oleh } \\
\text { jamur }\end{array}$ \\
\hline
\end{tabular}




\begin{tabular}{|c|c|c|c|c|c|}
\hline No & Bahasa lokal & $\begin{array}{c}\text { Organ } \\
\text { tanaman } \\
\text { yang } \\
\text { digunakan }\end{array}$ & Khasiat & Cara meramu & Cara penggunaan \\
\hline 13 & Tawa dambu & Daun & $\begin{array}{l}\text { Mengobati } \\
\text { sakit perut } \\
\text { (diare) }\end{array}$ & $\begin{array}{l}\text { Mengambil segenggam } \\
\text { daun muda tanaman } \\
\text { tersebut, selanjutnya } \\
\text { direbus dengan tiga } \\
\text { gelas air hingga tersisa } \\
\text { satu gelas }\end{array}$ & $\begin{array}{l}\text { Meminum air } \\
\text { rebusan daun } \\
\text { tersebut }\end{array}$ \\
\hline 14 & Lo'io & Rimpang & $\begin{array}{l}\text { Mengobati } \\
\text { infeksi } \\
\text { tenggorokan } \\
\text { dan masuk } \\
\text { angin }\end{array}$ & $\begin{array}{l}\text { Mengambil satu ruas } \\
\text { jari, kemudian diiris } \\
\text { tipis dan direbus } \\
\text { dengan tiga gelas air } \\
\text { hingga tersisa satu } \\
\text { gelas }\end{array}$ & $\begin{array}{l}\text { Meminum air } \\
\text { rebusan tersebut }\end{array}$ \\
\hline 15 & O'kudu & Rimpang & $\begin{array}{l}\text { Mengobati } \\
\text { infeksi } \\
\text { tenggorokan } \\
\text { dan dan sakit } \\
\text { kepala }\end{array}$ & $\begin{array}{l}\text { 1. Mengambil satu } \\
\text { ruas jari, kemudian } \\
\text { diiris tipis dan } \\
\text { direbus dengan } \\
\text { tiga gelas air } \\
\text { hingga tersisa satu } \\
\text { gelas } \\
\text { 2. Mengambil satu } \\
\text { ruas jari kencur, } \\
\text { kemudian } \\
\text { dihaluskan }\end{array}$ & $\begin{array}{l}\text { Air rebusan } \\
\text { tersebut diminum } \\
\text { selagi hangat } \\
\text { Ditempelkan } \\
\text { dibagian kepala } \\
\text { (jidat) }\end{array}$ \\
\hline 16 & O’bite & Daun & $\begin{array}{l}\text { Sebagai } \\
\text { antiseptik pada } \\
\text { wanita }\end{array}$ & $\begin{array}{l}\text { Merebus segenggam } \\
\text { daun tanaman } \\
\text { tersebut. }\end{array}$ & $\begin{array}{l}\text { Air rebusan } \\
\text { digunakan obat } \\
\text { cebok }\end{array}$ \\
\hline 17 & Taluede & Daun & $\begin{array}{l}\text { Mengobati } \\
\text { darah putih } \\
\text { yang tinggi } \\
\text { pada ibu hamil }\end{array}$ & $\begin{array}{l}\text { Bagian daun tanaman } \\
\text { diremas hingga berarir }\end{array}$ & Usapkan dikepala \\
\hline
\end{tabular}

Sebagian besar sumber pengetahuan masyarakat (emik) dari suku Tolaki tentang tanaman yang digunakan sebagai obat juga telah didukung oleh data ilmiah dan sains (etik). Kesesuaian emik dan etik ini membawa manfaat sehingga sangat potensial dikembangkan sebagai obat herbal dimasa yang akan datang. Umumnya tanaman herbal dari golongan Zingiberaceae, telah memberikan banyak sumbangsih dalam dunia pengobatan tradisional (Mackinnon et al., 2000). Meliki et al. (2013) menyatakan famili Zingiberaceae banyak dijadikan sebagai bahan obat oleh Suku Dayak. Begitupun dengan Suku Tolaki di Desa Puundoho Kolaka Utara, beberapa contoh Zingiberaceae yang digunakan oleh Suku Tolaki di tempat tersebut diantaranya jahe, kencur dan bangle.

Suku Tolaki pada daerah tersebut secara empiris telah menggunakan Jahe sebagai obat pada radang tenggorokan. Hal ini sejalan dengan penelitian yang dilakukan oleh Tima et al. (2020) pada Masyarakat di Kecamatan Nangapanda Kabupaten Ende Nusa Tenggara Timur. Hasil 
penelitian tersebut menyebutkan bahwa jahe digunakan sebagai obat luar dan mengobati sakit tenggorokan. Winarti \& Nurdjanah (2005) menyatakan kandungan gingerol yang terdapat dalam rimpang jahe memiliki aktivtas antioksidan. Samsudin et al. (2016) juga menyatakan bahwa jahe mengandung senyawa saponin, flavonoid, polifenol dan minya atsiri yang dapat digunakan untuk mengurangi rasa nyeri pada penderita gout artritis. Kencur pada komunitas ini digunakan untuk mengobati infeksi tenggorokan dan sakit kepala. Larasati et al. (2019) menyatakan bahwa golongan Zingiberaceae seperti pada kencur, memiliki kandungan senyawa flavonoid, saponin, polifenol dan minyak atsiri yang memiliki aktivitas antibakeri. Hasil penelitian Fajeriyati \& Andika (2017) menyebutkan bahwa ekstrak etanol rimpang kencur dapat menghambat pertumbuhan Bacillus subtilis dan Escherichia coli. Rostiana \& Effendi (2007) juga menyatakan bahwa kencur dapat menambah nafsu makan, ekspektoran, obat batuk, disentri, tonikum, infeksi bakteri, masuk angin, dan sakit perut. Bangle digunakan untuk mengobati sakit perut, diare berdarah dan demam. Hasil penelitian tersebut sesuai dengan peneliatan Iswantini et al. (2011), Marliani (2012) dan Wulansari et al. (2016), yang menyebutkan bahwa bangle mengandung senyawa saponin, flavonoid, minyak atsiri, alkaloid, tanin, dan glikosida yang dapat menghambat pertumbuhan bakeri, laksatif, antioksidan, dan mampu menghambat lipase pankreas.

Simplisia yang digunakan sebagai obat tradisional oleh suku Tolaki mayoritas berasal dari daun. Hal ini menandakan bahwa kearifan lokal masyarakat Suku Tolaki dapat dijelaskan secara ilmiah. Daun adalah bagian yang paling mudah diperoleh dari suatu tumbuhan dan sering digunakan dalam pengobatan (Karmilasanti \& Supartini, 2011). Santoso \& Hariyadi (2008) menyatakan bahwa daun pada umumnya bertekstur lunak sebab mempunyai kandungan air yang tinggi, merupakan tempat fotosintesis, sehingga mengandung berbagai zat organik atau metabolit sekunder berupa alkaloid, flavonoid, saponin dan terpenoid yang sangat potensial digunakan sebagai sumber obat-obatan. Meskipun daun adalah tempat fotosintesis, tetapi daun memiliki regenerasi yang tinggi, sehingga tidak berdampak besar terhadap keberlangsungan hidup suatu tumbuhan, berbeda jika pemanfaatan tumbuhan adalah akar dan batangnya. Dikhawatirkan dapat mengganggu keberlangsungan dan regenerasi tumbuhan tersebut. Hal ini menunjukkan bahwa meskipun Suku Tolaki di daerah ini banyak menggunakan tanaman dalam kehidupan, misalnya sebagai obat-obatan, namun kearifan lokal suku ini sangat menjunjung nilai atau budaya konservasi.

Beberapa contoh tumbuhan obat suku Tolaki yang berbahan daun yaitu daun jambu biji, daun sirih dan daun bandotan. Hasil penelitian Rizal \& Sustriana (2019) di Kabupaten Musi Banyuasin, Sumatera Selatan terlihat bahwa masyarakat juga memanfaatkan sirih, jambu biji sebagai bahan obat-obatan. Masyarakat Suku Tolaki menggunakan daun jambu biji sebagai obat sakit perut. Hal ini sesuai dengan Tannaz et al. (2014) \& Fratiwi (2015) yang menyatakan tanaman jambu biji, terutama bagian daun memiliki efektivitas yang lebih tinggi sebagai antidiare 
dikarenakan tanaman ini mengandung tanin, flavonoid, alkoloid dan minyak atsiri yang dapat menghilangkan rasa sakit di perut. Penggunaan daun sirih sebagai antiseptik pada wanita oleh Suku Tolaki juga sesuai dengan hasil penelitian (Supratiknyo, 2015). Hasil penelitian tersebut menyatakan bahwa rebusan daun sirih dapat digunakan untuk mengobati keputihan patologis. Manek et al. (2019) juga menyebutkan sirih dapat digunakan untuk mengobati keputihan pada masyarakat Desa Lookeu Kecamatan Tasifeto Barat Kabupaten Belu Nusa Tenggara Timur. Sirih dapat digunakan untuk mengobati beberapa penyakit antara lain mengobati diare, mengobati sakit gigi, mimisan, dan mengatasi keputihan dan masalah kesehatan wanita lainnya sirih mengandung senyawa bioaktif antara lain metil eugenol, sineol, estragol, karvakrol, tanin, alkaloid, flavonoid, antrakuinon dan komponen steroid (Suarsana et al., 2015). Suku Tolaki menggunakan daun bandotan untuk mencegah pendarahan karena luka. Hal ini sejalan dengan penelitian Amadi et al. (2012) yang menyatakan bahwa kandungan alkaloid dan flavonoid terakumulasi pada daun bandotan dapat meningkatan proliferasi seluler pada lokasi luka yang disebabkan oleh sintesis kolagen yang mengalami pengendapan, dengan cara regenerasi dermal dan epidermal dini, memiliki efek positif terhadap proliferasi seluler, pembentukan jaringan granular dan epitelisasi.

Selain berbahan daun, simplisia yang digunakan suku Tolaki juga dapat berasal dari keseluruhan tumbuhan, misalnya tumbuhan ciplukan, dan krokot. Suku Tolaki menggunakan tanaman ciplukan untuk mengobati kolesterol, sakit perut, gondok beracun. Hal ini sesuai dengan penelitian Krishna et al. (2013) yang menyatakan bahwa ciplukan memiliki aktivitas sebagai antioksidan, antiartritis dan antiinflamasi, dan imunomodulator. Hal ini dikarenakan ciplukan mengandung senyawa flavonoid, yang berpotensi sebagai antioksidan pada pertumbuhan tumor sehingga dapat meningkatkan respon imun. Suku Tolaki menggunakan krokot untuk penyakit jantung. Hal ini sesuai dengan teori yang menyatakan bahwa krokot berperan untuk menurunkan total kolesterol, trigliserida, LDL (low densitiy lipoprotein) dan meningkatkan HDL (high density lipoprotein). Masyarakat Suku Tolaki menggunakan meniran untuk mengobati infeksi saluran kemih. Penelitian Tambunan et al. (2019) menyatakan bahwa kandungan senyawa kimia yang terdapat pada herba meniran antara lain saponin, flavonoid, polifenol, filantin, hipofilantin, dan garam kalium. Senyawa-senyawa tersebut saling berinteraksi sehingga dapat meningkatkan aktivitas antioksidannya.

Suku Tolaki menggunakan kulit batang mesoyi untuk menyembuhkan luka. Hal ini sesuai dengan penelitian Prasetyo et al. (2019) yang menyatakan bahwa minyak atsiri mesoyi yang diperoleh dari kulit batang terbukti dapat menghambat pertumbuhan bakteri Streptococcus mutans. Masyarakat suku Tolaki menggunakan sidaguri untuk mengobati bisul dan buang air besar yang disertai darah. Syafrullah (2015) menyatakan bahwa sidaguri memiliki kandungan flavonoid, alkaloid dan leuokoantosionidan. Sidaguri oleh masyarakat Suku Muna di permukiman 
Kota Wuna digunakan sebagai ramuan setelah melahirkan. Ramuan tersebut berkhasiat untuk membersihkan darah kotor, memulihkan tenaga dan mengencangkan kembali bagian tubuh yang kendor setelah melahirkan (Jumiarni \& Komalasari, 2017). Jeringau oleh masyarakat suku Tolaki digunakan untuk mengobati sakit perut (diare). Penelitian dari Widyastuti et al. (2019) pada suku Devayan di Aceh menyebutkan bahwa Jeringau dapat digunakan untuk mengobati diare, batuk, demam/panas, HIV/AIDS, perawatan pra/pasca melahirkan, sakit kepala, dan tumor/kanker. Hal ini dikarenakan rimpang Jeringau memiliki kandungan zat aktif yaitu $\beta$-asaron, $\alpha$-asaron, seskuiterpen, $\beta$-daucosterol, triterpenoid, dan polisakarida larut air (Nandakumar et al., 2012).

Tanaman turi digunakan oleh masyarakat suku Tolaki untuk mengobati panas dalam. Hal ini dimungkinkan karena tanaman turi mengandung senyawa kimia berupa arginin, sistein, histidin, isoleusin, fenilalanin, triptofan, valin, treonin, alanine, aspargin, asam aspartat, saponin, asam oleat, galaktosa, ramnosa, asam glukoronat, flavonoid, dan kaemferol yang mempengaruhi aktivitas tersebut (Bhoumik et al., 2016).

Masyarakat suku Tolaki menggunakan boborongan untuk menghilangkan bau amis pada haid. Hal ini sesuai dengan penelitian Falah et al. (2013) pada masyarakat disekitar hutan lindung Gunung Beratus Kalimantan Timur. Hasil penelitian tersebut menyebutkan bahwa tanaman boborongan digunakan untuk pengobatan pasca persalinan dan penghilang bau amis darah (Falah et al., 2013). Hal ini dikarenakan tanaman tersebut mengandung minyak esensial seperti germacrene D (13,54\%), caryophyllene $(12,31 \%)$, phthalamide doxime $(9,47 \%)$, caryophyllene oxide $(8,87 \%)$, §-elemene $(7,18 \%)$, caryophyllene $(4,83 \%)$, carotol $(3,83 \%)$, juniper camphor $(3,70 \%)$, ledol (3,08\%), §-eudesmol (2,50\%) dan lain-lain yang berperan sebagi obat (Bhuiyan et al., 2010).

Rumput banjan/beriwit oleh masyarakat Suku Tolaki digunakan untuk mencegah pendarahan pada luka. Hal ini sesuai dengan penelitian Noorcahyati (2012) pada masyarakat etnis asli Kalimantan. Hasil penelitian tersebut menyebutkan bahwa rumput banjan/beriwit dapat digunakan untuk mengobati luka terbuka. Hal ini dikarenakan tanaman tersebut mengandung glikosida, saponin, steroid, flavonoid, tannin, alkaloid dan triterpenoid. Khasiat glikosida dalam rumput banjan antara lain menunjukkan aktivitas terapetik seperti aktivitas anti inflamasi, aktivitas antioksidan, antivitas antidiabetik, antibakteri, antivirus, anti kanker, anti tumor dan aktivitas biologis lainnya (Garduque et al., 2019).

Masyarakat Suku Tolaki menggunakan paku blechnum (Brachnum orientale) untuk membantu menurunkan kadar darah putih yang tinggi pada ibu hamil. Hal ini sesuai dengan penelitian Nikmatullah et al. (2020) yang menyebutkan bahwa paku brachnum dapat digunakan untuk mengobati penyakit bisul, cacingan, diare, gangguan saluran kemih, kebingungan akut (igauan), kontrasepsi alami, kulit gatal, luka, leukemia, maag, sakit kepala, sakit telinga, sakit perut dan tifus. Kandungan senyawa kimia pada paku blechnum yaitu blechnic acid, 8-epiblechnic acid, 
brainic acid, 22-dehydrocampesterol, 24-alpha-ethyl- cholest-5-en-3-beta-ol, 24-alphaethyl-methylcholest-5- en-3-beta-ol, 24-beta-methyl-cholest-5-en-3-beta-ol, 24- alpha-cholest-5 dan 22-dien-3beta-ol. Paku blechnum menunjukkan beberapa aktivitas farmakologi antara lain aktivitas antioksidan, antidiabetik dan antimikroba (Kumar et al., 2015).

\section{Kesimpulan}

Berdasarkan hasil penelitian, maka dapat disimpulkan bahwa jenis tanaman obat tradisional yang digunakan oleh Suku Tolaki di desa Puundoho dapat diperoleh dari pekarangan, kebun, dan pinggir jalan diantaranya sidaguri, ciplukan, jeringan, bangle, krokot, bandotan, boborongan, turi, meniran, rumput beriwit banjar, mesoyi, ketepeng, jambu air, jahe, kencur, paku blechnum dan ketepeng. Akan tetapi, kemungkinan masih ada jenis tumbuhan lain yang berperan sebagai obat dan belum terekspos.

\section{Ucapan terimakasih}

Terima kasih kami ucapkan kepada Bapak Samsir Sabar selaku Kepala Desa Puundoho yang telah memberi ijin pelaksaaan penelitian serta penyehat tradisional suku Tolaki yang telah membantu jalannya penelitian ini.

\section{Daftar pustaka}

Van-Steenis, C. G. G. J. (2005). Flora. Jakarta: Pradnya Paramita.

Amadi, B. A., Duru, M. K. C., \& Agomuo, E. N. (2012). Chemical profilesof leaf, stem, root and flower of Ageratum conyzoides. Asian Journal of Plant Science, 2(4), 428-432.

Bhoumik, D., Berhe, A. H., \& Mallik, A. (2016). Evaluation of gastric anti-ulcer potency of ethanolic extract of Sesbania grandiflora Linn leaves in experimental animals. American Journal of Phytomedicine Clinical Therapeutics, 4(6), 174-182.

Bhuiyan, M. N. I., Begum, J., \& Nandi, N. C. (2010). Chemical component studies on the leaf and inflorescence essential oil of Hyptis brevipes (Poit.). Journal of Medicinal Plants Research, $4(20), 2128-2131$.

Fajeriyati, N., \& Andika, A. J. J. (2017). Uji Aktivitas Antibakteri Ekstrak Etanol Rimpang Kencur (Kaempferia galanga L.) pada Bakteri Bacillus subtilis dan Escherichia coli. Journal of Current Pharmaceutical Sciences, 1(1), 36-41.

Falah, F., Sayektiningsih, T., \& Noorcahyati, N. (2013). Keragaman jenis dan pemanfaatan tumbuhan berkhasiat obat oleh masyarakat sekitar Hutan Lindung Gunung Beratus, Kalimantan Timur. Jurnal Penelitian Hutan dan Konservasi Al, 10(1), 1-18.

Fratiwi, Y. (2015). The potential of guava leaf (Psidium guajava L.) for diarrhea. Jurnal Majority, 4(1), 113-118.

Garduque, D. A., Mateo, K. R., \& Oyinloye, S. M. (2019). Antimicrobial Efficacy of Carabao Grass (Paspalum conjugatum) leaves on Staphylococcus aureus. Paper presented at the Abstract Proceedings International Scholars Conference.

Hasanah, N., Sudrajat, H. W., \& Damhuri, D. (2016). Etnobotani tumbuhan obat masyarakat Desa Lapandewa Kaindea Kecamatan Lapandewa Kabupaten Buton Selatan. Jurnal AMPIBI, 1(1), 14-20. 
Indrawati, I., Sabilu, Y., \& Zainal, P. F. (2015). Keanekaragamaan dan Pemanfaatan Tumbuhan Obat Tradisional Pada Masyarakat di Kelurahan Lipu Kecamatan Betoambari Kota Baubau Provinsi Sulawesi Tenggara. BioWallacea, 2(1), 204-210.

Iswantini, D., Silitonga, R. F., Martatilofa, E., \& Darusman, L. K. (2011). Zingiber cassumunar, Guazuma ulmifolia, and Murraya paniculata extracts as antiobesity: in vitro inhibitory effect on pancreatic lipase activity. Hayati Journal of Biosciences, 18(1), 6-10. doi:DOI: 10.4308/hjb.18.1.6

Jamshidi-Kia, F., Lorigooini, Z., \& Amini-Khoei, H. (2018). Medicinal plants: Past history and future perspective. Journal of herbmed pharmacology, 7(1), 1-7. doi:doi: 10.15171/jhp.2018.01

Jumiarni, W. O., \& Komalasari, O. (2017). Eksplorasi jenis dan pemanfaatan tumbuhan obat pada masyarakat Suku Muna di Permukiman Kota Wuna. Traditional Medicine Journal, 22(1), 4556.

Karmilasanti, K., \& Supartini, S. (2011). Keanekaragaman Jenis Tumbuhan Obat dan Pemanfaatannya di Kawasan Tane'olen Desa Setulang Malinau, Kalimantan Timur. Jurnal Penelitian Ekosistem Dipterokarpa, 5(1), 23-38.

Krishna, T. M., Vadluri, R., \& Kumar, E. M. (2013). In vitro determination of antioxidant activity of Physalis angulata Lnn. International Journal of Pharmacy Bio Sciences, 4(3).

Kumar, D. G., Syafiq, A. M., Ruhaiyem, Y., \& Shahnaz, M. (2015). Blechnum orientale Linn: An important edible medicinal fern. International Journal of Pharmacognosy Phytochemical Research, 7(4), 723-726.

Kuntorini, E. M. (2005). Botani ekonomi suku Zingiberaceae sebagai obat tradisional oleh masyarakat di Kotamadya Banjarbaru. Jurnal Bioscientiae, 2(1), 25-36.

Larasati, A., Marmaini, M., \& Kartika, T. (2019). Inventarisasi Tumbuhan Berkhasiat Obat di Sekitar Pekarangan di Kelurahan Sentosa. Jurnal Indobiosains, 1(2), 76-87.

Mackinnon, K., Hatta, G., Halim, H., \& Mangalik, A. (2000). Seri Ekologi Indonesia, Buku III: Ekologi Kalimantan. Jakarta: Prenhallindo.

Manek, M. N., Boro, T. L., \& Ruma, M. T. L. (2019). Identifikasi Jenis-Jenis Tumbuhan Berkhasiat Obat Di Desa Lookeu Kecamatan Tasifeto Barat Kabupaten Belu. Jurnal Biotropikal Sains, 16(1), 6477.

Marliani, L. (2012). Aktivitas antibakteri dan telaah senyawa komponen minyak atsiri rimpang bangle (Zingiber cassumunar Roxb.). Prosiding SNaPP2012: Sains, Teknologi, dan Kesehatan, 3(1), 1-6.

Meliki, M., Linda, R., \& Lovadi, I. (2013). Etnobotani Tumbuhan Obat oleh Suku Dayak Iban Desa Tanjung Sari Kecamatan Ketungau Tengah Kabupaten Sintang. Jurnal Protobiont, 2(3), 129135.

Nandakumar, S., Menon, S., \& Shailajan, S. (2012). A rapid HPLC-ESI-MS/MS method for determination of $\beta$-asarone, a potential anti-epileptic agent, in plasma after oral administration of Acorus calamus extract to rats. Biomedical Chromatography, 27(3), 318326. doi:DOI 10.1002/bmc.2794

Nikmatullah, M., Renjana, E., Muhaiman, M., \& Rahayu, M. (2020). Potensi Tumbuhan Paku (Ferns \& Lycophytes) Yang Dikoleksi Di Kebun Raya Cibodas Sebagai Obat. Al-kauniyah: Jurnal Biologi, 13(2), 278-287. doi:dx.doi.org/10.15408/kauniyah.v13i2.16061

Noorcahyati, N. (2012). Tumbuhan Berkasiat Obat Etnis Asli Kalimantan. In.

Pei, S., Zhang, G., \& Huai, H. (2009). Application of traditional knowledge in forest management: Ethnobotanical indicators of sustainable forest use. Forest Ecology and Management, 257, 2017-2021. doi:doi:10.1016/j.foreco.2009.01.003

Prasetyo, Y. S. A., Sitepu, R., \& Rollando, R. (2019). Uji Antimikroba Minyak Atsiri Mayosi (Massoia aromatica) terhadap Bakteri Streptococcus mutans. Jurnal Farmasi dan Kesehatan, 9(2), 132140.

Qamariah, N., Mulyani, E., \& Dewi, N. (2018). Inventarisasi Tumbuhan Obat di Desa Pelangsian Kecamatan Mentawa Baru Ketapang Kabupaten Kotawaringin Timur. Borneo Journal of Pharmacy, 1(1), 1-10.

Rahayu, M., \& Rugayah, R. (2007). Pengetahuan Tradisional dan Pemanfaatan Tumbuhan oleh Masyarakat Lokal Pulau Wawonii Sulawesi Tenggara Berita Biologi, 8(6), 489-499. 
Rahim, N. (2013). Identifikasi Tumbuhan Berkhasiat Obatyang Digunakan oleh Pengobat Tradisional Suku Bajo di Desa Torosiaje. (1), Universitas Negeri Gorontalo, (431409046)

Rizal, S., \& Sustriana, S. (2019). Inventarisasi dan Identifikasi Tanaman Bekhasiat Obat di Kabupaten Musi Banyuasin Sumatera Selatan. Jurnal Indobiosains, 1(2), 50-62.

Rostiana, O., \& Effendi, D. S. (2007). Teknologi Unggulan Kencur: Perbenihan dan Budidaya Pendukung Varietas Unggul. In.

Samsudin, A. R. R., Kundre, R., \& Onibala, F. (2016). Pengaruh Pemberian Kompres Hangat Memakai Parutan Jahe Merah (Zingiber Officinale Roscoe Var Rubrum) Terhadap Penurunan Skala Nyeri PadaPenderitaGout Artritis Di Desa Tateli Dua Kecamatan Mandolang Kabupeten Minahasa. eJurnal Keperawatan, 4(1).

Santoso, B. B., \& Hariyadi, H. (2008). Metode pengukuran luas daun jarak pagar (Jatropha curcas L.). MAGROBIS-Jurnal Ilmu-Ilmu Pertanian, 8(1), 17-22.

Setyowati, F. M., \& Wardah, W. (2007). Diversity of medicinal plant by Talang Mamak tribe in surrounding of Bukit Tiga Puluh National Park, Riau. Biodiversitas, 8(3), 228-232.

Slamet, A., \& Andarias, S. H. (2018). Studi Etnobotani dan Identifikasi Tumbuhan Berkhasiat ObatMasyarakat Sub Etnis Wolio Kota Baubau Sulawesi Tenggara. Paper presented the Proceeding Biology Education Conference.

Sofian, F. F., Supriyatna, S., \& Moektiwardoyo, M. (2013). Peningkatan sikap positif masyarakat dalam pemanfaatan tanaman obat pekarangan rumah di Desa Sukamaju dan Girijaya Kabupaten Garut. Jurnal Aplikasi Ipteks untuk Masyarakat, 2(2), 107-117.

Suarsana, I. N., Kumbara, A. A. N. A., \& Satriawan, I. K. (2015). Tanaman Obat Sembuhkan Penyakit untuk Sehat. In (pp. $126 \mathrm{hlm}$ ).

Supratiknyo, S. (2015). Kecepatan Kesembuhan Keputihan Patologis dengan Intervensi Rebusan Daun Sirih. Oksitosin, Kebidanan, 2(1), 41-48.

Syafrullah, S. C. (2015). Indonesian sidaguri (Sida rhombifolia L.) as antigout and inhibition kinetics of flavonoids. Jurnal Majority, 4(1), 80-85.

Tambunan, R. M., Swandiny, G. F., \& Zaidan, S. (2019). Uji Aktivitas Antioksidan dari Ekstrak Etanol 70\% Herba Meniran (Phyllanthus niruri L.) Terstandar. Jurnal Ilmu Kefarmasian, 12(2), 6064 .

Tannaz, J. B., Brijesh, S., \& Daswani, P. G. (2014). Bactericidal effect of selected antidiarrhoeal medicinal plants on intracellular heat-stable eterotoxinproducing Escherichia coli. Indian Journal of Pharmaceutical Sciences, 76(3), 229-235.

Tima, M. T., Wahyuni, S., \& Murdaningsih, M. (2020). Etnobotani Tanaman Obat di Kecamatan Nangapanda Kabupaten Ende Nusa Tenggara Timur. Journal Penelitian Kehutanan FALOAK, 4(1), 23-38. doi:doi.org/10.20886/jpkf.2020.4.1

Tjitrosoepomo, G. (2005). Taksonomi Tumbuhan Obat-Obatan Cetakan ke-2. Yogyakarta: Gadjah Mada University Press.

Widyastuti, R., Ratnawati, G., \& Saryanto, S. (2019). Penggunaan Tumbuhan Jerango (Acorus Calamus) Untuk Pengobatan Berbagai Penyakit Pada Delapan Etnis Di Provinsi Aceh. Media Konservasi, 24(1), 11-19.

Wijayakusuma, H. M. H. (2000). Potensi Tumbuhan Obat Asli Indonesia sebagai Produk Kesehatan. Risalah Pertemuan Ilmiah Penelitian dan Pengembangan Teknologi Isotop dan Radiasi, 25-31.

Winarti, C., \& Nurdjanah, N. (2005). Peluang tanaman rempah dan obat sebagai sumber pangan fungsional. Jurnal Litbang Pertanian, 24(2), 47-55.

Windadri, F. I., Rahayu, M., Uji, T., \& Rustiami, H. (2006). Pemanfaatan tumbuhan sebagai bahan obat oleh masyarakat lokal suku Muna di kecamatan Wakarumba, kabupaten Muna, Sulawesi Utara. Biodiversitas, 7(4), 333-339.

Wulansari, E. D., Wahyuono, S., Marchaban, M., \& Widyarini, s. (2016). Potential Bengle (Zingiber cassumunar Roxb.) rhizomes for sunscreen and antioxidant compounds. International Journal of PharmTech Research, 9(11), 72-77.

Yowa, M. K., Boro, T. L. B., \& Danong, M. T. (2019). Inventarisasi Jenis-jenis Tumbuhan Berkhasiat Obat Tradisional di Desa Umbu Langang Kecamatan Umbu Ratu Nggay Barat Kabupaten Sumba Tengah. Jurnal Biotropikal Sains, 16(1), 1-13. 
33 | Hasri, A. /Jurnal Ilmiah Farmasi (Scientific Journal of Pharmacy) 17(1) Januari-Juli 2021, 19-33

Yuan, H., Ma, Q., Ye, L., \& Piao, G. (2016). The traditional medicine and modern medicine from natural products. Molecules, 21(5), 1-18. 